\title{
Evaluation of Substrates for Jenipapo (Genipa americana L.) Seedlings Production
}

\author{
Ana Veruska Cruz da Silva ${ }^{1}$, Adrielle Naiana Ribeiro Soares ${ }^{2}$, Milena Nascimento Cardoso ${ }^{2}$, \\ Marília Freitas de Vasconcelos Melo ${ }^{3}$, Evandro Neves Muniz ${ }^{1} \&$ Ana da Silva Ledo ${ }^{1}$ \\ ${ }^{1}$ Embrapa Coastal Tablelands, Aracaju, Sergipe, Brazil \\ ${ }^{2}$ Federal University of Sergipe, São Cristovão, Sergipe, Brazil \\ ${ }^{3}$ Federal University of Alagoas, Rio Largo, Alagoas, Brazil \\ Correspondence: Ana Veruska Cruz da Silva, Embrapa Coastal Tablelands, Av. Beira mar, 3250-49025-040 \\ Aracaju, SE, Brazil. Tel: 55-79-4009-1362. E-mail: ana.veruska@embrapa.br
}

Received: October 27, 2017

Accepted: December 10, 2017 Online Published: January 15, 2018

doi:10.5539/jas.v10n2p352

URL: https://doi.org/10.5539/jas.v10n2p352

The research is financed by Embrapa.

\begin{abstract}
Jenipapo (Genipa americana L. Rubiaceae) is a native species not endemic to Brazil and found in several biomes. The objective of this work was to evaluate the emergence and growth of seedlings cultivated in different substrates. Treatments were made of: T1 (fertilized soil), T2 (fertilized soil + coconut fiber), T3 (fertilized soil + sand), T4 (sand + coconut fiber), T5 (bovine manure + coconut fiber), and T6 (bovine manure + sand). The experiment consisted of a completely randomized design, with six treatments (substrates) and four replications of 25 seeds. The following variables were evaluated: first emergence count, percentage of emergence, emergence speed index, seedling height, root length, stem diameter, number of leaves, relative chlorophyll content (SPAD), leaf area, root dry matter, and shoot dry matter. The substrates T1 (fertilized soil), T2 (fertilized soil + coconut fiber), T3 (fertilized soil + sand) and T6 (bovine manure + sand) were more efficient for jenipapo seedlings production.
\end{abstract}

Keywords: tropical fruits, propagation, organic waste

\section{Introduction}

Jenipapo (Genipa americana L. Rubiaceae) is a fruitful species native to tropical America, with wide occurrence in Brazil. Besides its nutritional and pharmaceutical relevance, the species presents ornamental potential. $G$. americana can be used for the reforestation of urban areas due to its dense pyramidal crown with short branches (Almeida et al., 2015), being highly recommended for the recovery of riparian forests. The fruit is rich in genipin, a natural, low-toxic blue dye.

The cultivation is predominantly extractivist, revealing the need for the development of studies that address cultivation and propagation forms. Works on substrate type are fundamental for seedlings germination and establishment (Coelho et al., 2010). Despite the reports available in the literature on germinative behavior, information about the mechanism and control of Genipa americana germination is still scarce (Queiroz et al., 2012).

Validating a methodology for seeds of Brazilian forest species requires technological and scientific knowledge. However, there is a bottleneck in relation to information about them. Usually, studies provide only the percentage of germinated seeds, which hinders the official conversion of these methods into official US, Canadian, and European rules (Santana et al., 2012). These studies may contribute to the development of technologies to improve seedling production of fruit species native to Brazil.

Research on the seed technology of species native to Brazil is still incipient, and the Rules for Seed Analysis (RSA) are limited in relation these species (Osipi et al., 2011). The study on seeds germination behavior and native seedlings growth can contribute to improving the species propagation and conservation since little is 
known about these processes and they are usually disregarded during the planning and production (Abud et al., 2009).

Seedling germination and growth are influenced by substrate quality. Factors such as aeration, structure, and moisture retention capacity may vary between different substrates, favoring or impairing seed germination (Moraes et al., 2007). Substrate porosity must be significant to allow an efficient gas exchange, benefiting root respiration and microorganisms' activity.

The choice of the best formulation and the reduction of seedling production costs have led to the study of alternative substrates (Mesquita et al., 2011). The use of substrates composed of organic residues has intensified in recent years, allowing improvements in the production of native Brazilian forest seedlings (Freitas et al., 2014).

Jenipapo has a great potential to be explored; however, some bottlenecks, such as the lack of varieties and seeds sensitivity to dehydration, with loss of viability in the short term, together with slow and uneven germination still prevent its commercial exploitation (Magistrali et al., 2013).

The objective of this study was to evaluate the emergence and growth of jenipapo for 90 days under different types of substrates.

\section{Method}

The experiment was carried out in a greenhouse located at Embrapa Coastal Tablelands, in Aracaju, Brazil. Fruits were collected from native trees, located in the municipality of Arauá, SE $\left(11^{\circ} 15^{\prime} 22^{\prime \prime} \mathrm{S}, 37^{\circ} 37^{\prime} 30^{\prime \prime} \mathrm{W}\right.$, at 86 $\mathrm{m}$ asl.), stored in plastic bags, and taken to the Seed Analysis Laboratory of the institution. Fruits were pulped using a small-hole mesh sieve. Seeds were washed in tap water for complete pulp removal and allowed to dry for $12 \mathrm{~h}$ at $25^{\circ} \mathrm{C}$. Afterward, seeds were subjected to treatments with different types of substrate (Table 1).

Table 1. Substrates used for seed germination and seedling growth of Genipa americana L.

\begin{tabular}{ll}
\hline Treatments & Substrate components $(1: 1$ ratio $)$ \\
\hline T1 & Fertilized soil \\
T2 & Fertilized soil + coconut fiber \\
T3 & Fertilized soil + sand \\
T4 & Sand + coconut fiber \\
T5 & Bovine Manure + coconut fiber \\
T6 & Bovine Manure + sand \\
\hline
\end{tabular}

All combinations of the substrates were determined by the ratio 1: 1. Sowing was performed at $1 \mathrm{~cm}$ depth, using black polyethylene bags $(20 \mathrm{~cm} \times 15 \mathrm{~cm})$. Irrigation was performed daily at 9 am and $4 \mathrm{pm}$. The following traits were evaluated:

First emergence count: Corresponded to the accumulated percentage of normal plants, with values recorded at 15 days after experiment installation.

Percentage of emergence: Obtained according to the recommendations of the Rules for Seed Analysis (RSA) (Brasil, 2009), under greenhouse conditions, at $30 \pm 3{ }^{\circ} \mathrm{C}$. The counts began at 15 days after experiment installation. Percentage of emergence was measured at 90 days after sowing, with the emergence of the cotyledons on the substrate, followed by the appearance of the hypocotyl.

Emergence speed index: Performed simultaneously to the emergence test, with daily counts at 8 a.m., from the fifteenth day after the experiment installation. This index was calculated according to the formula ESI $=\mathrm{E} 1 / \mathrm{N} 1+$ $\mathrm{E} 2 / \mathrm{N} 2+\ldots \mathrm{En} / \mathrm{Nn}$, where, ESI = emergence speed index, E1, E2, and En = number of normal emerged plants, computed in the first, second ... and last count, respectively; N1, N2, Nn = number of sowing days at the first, second ... and last count, respectively (Maguire, 1962).

The following traits were measured at the end of the experiment, that is, at 90 days after sowing:

Seedling height: The distance between the soil and the apex of the plant, measured with the aid of a graduated ruler $(\mathrm{cm})$;

Root length: The full extent of roots, measured using a graduated ruler $(\mathrm{cm})$;

Stem diameter: Measured by a digital caliper (SE® model 784EC, CA, USA), expressed in cm; 
Number of leaves: Determined by counting the leaves of each plant;

Leaf area: Measured using a leaf area meter (LI-COR LI3100C), expressed in $\mathrm{dm}^{2}$;

Leaf area ratio: Obtained by the relation between the leaf area and the total plant dry matter, expressed in $\mathrm{dm}^{2}$ $\mathrm{g}^{-1}$;

Relative chlorophyll content (SPAD): Determined using a chlorophyllometer (Minolta ${ }^{\circledR}$ Spad 502, Osaca, Japan), in the center of the leaves, in ten leaves per each treatment replication;

Shoot and root dry matter: Obtained by drying shoots and roots in an oven at $80^{\circ} \mathrm{C}$ for 24 , weighing in analytical scale, expressed in grams (Nakagawa, 1999).

The experiment consisted of a randomized blocks design, with four replications of 25 seeds, totaling 100 seeds per treatment. Data were subjected to analysis of variance, and the means were compared by the Tukey's test at $5 \%$ probability, using the SAS software.

\section{Results and Discussion}

The substrates presented significant differences for the first emergence count, percentage of emergence, and emergence speed index (Table 2). T4 (sand + coconut fiber) obtained the best results for these variables, with $72 \%$ in the first count, $99 \%$ in the total of emerged plants, and an ESI of 1.49. However, T4 was not significant in relation to T2 (soil fertilized + coconut fiber) for the percentage of emergence. Due to the lack of ideal humidity and oxygenation conditions, treatments T1 (fertilized soil), T3 (fertilized soil + sand), and T6 (bovine manure + sand) did not perform their maximum germination potential (Table 2).

Table 2. First emergence count (FEC\%), percentage of emergence (PE\%) and emergence speed index (ESI) of jenipapo seeds subjected to different substrate compositions

\begin{tabular}{llll}
\hline Treatments & FEC (\%) & PE (\%) & ESI (\%) \\
\hline T1 & $5 \mathrm{c}$ & $40 \mathrm{c}$ & $0.27 \mathrm{~d}$ \\
T2 & $22 \mathrm{~b}$ & $86 \mathrm{a}$ & $1.10 \mathrm{~b}$ \\
T3 & $6 \mathrm{c}$ & $61 \mathrm{~b}$ & $0.69 \mathrm{c}$ \\
T4 & $72 \mathrm{a}$ & $99 \mathrm{a}$ & $1.49 \mathrm{a}$ \\
T5 & $17 \mathrm{~b}$ & $54 \mathrm{~b}$ & $0.77 \mathrm{c}$ \\
T6 & $4 \mathrm{c}$ & $43 \mathrm{c}$ & $0.47 \mathrm{~d}$ \\
\hline CV $(\%)$ & 12.63 & 3.66 & 11.59 \\
\hline
\end{tabular}

Substrates composed of pure coconut fiber and coconut fiber mixed with sand resulted in higher emergence rates in paricá seeds (Schizolobium amazonicum Huber ex Ducke) (Gondin et al., 2015). In uvaia seeds (Eugenia pyriformis), percentage of emergence and emergence speed index (ESI) were higher in seeds cultivated in substrates containing organic compounds (Scalon \& Jeromine, 2013). Conversely, in canafístula seeds (Peltophorum dubium (Spreng.) Taubert), the highest percentage of plants emerged at the first count was observed with the use of washed sand substrate (Alves et al., 2011). In Hancornia speciosa Gomes seeds, the substrate containing organic compound resulted in a higher emergence speed index (Silva et al., 2009).

The satisfactory germinative behavior using T4 (sand + coconut fiber) and T2 (fertilized soil + coconut fiber) (Table 2) may be related to the water retention capacity of the coconut fiber, which is an essential factor for seed imbibition (Leal et al., 2016). Despite being poor in organic matter, sand may be advantageous for providing rapid seedlings emergence and root development (Gondin et al., 2015).

Substrates composed of organic residues allow adequate water absorption capacity for seedlings emergence, resulting in a greater uniformity of water availability for seeds (Araújo \& Paiva Sobrinho, 2011). The substrate significantly influenced seedlings emergence and initial growth. Coconut fiber is a viable alternative for seedlings production due to its easy handling, good water retention capacity, and light weight. In addition, this substrate does not require irrigation (Carrijo et al., 2002).

Treatments significantly influenced seedlings growth, confirmed by the seedling height, stem diameter, number of leaves, shoot dry matter, root dry matter, root length, and shoot length (Table 3). T6 (bovine manure + sand) resulted in greater seedling height and stem diameter, corresponding to $12.94 \mathrm{~cm}$ and $4.07 \mathrm{~mm}$, respectively. 
Table 3. Seedling height, stem diameter, root length, shoot dry matter, and root dry matter of jenipapo seedlings subjected to different substrate compositions

\begin{tabular}{llllll}
\hline Treatments & Seedling height $(\mathrm{cm})$ & Stem diameter $(\mathrm{mm})$ & Root length $(\mathrm{cm})$ & Shoot dry matter $(\mathrm{g})$ & Root dry matter $(\mathrm{g})$ \\
\hline T1 & $6.34 \mathrm{c}$ & $4.04 \mathrm{a}$ & $21.30 \mathrm{~b}$ & $7.95 \mathrm{c}$ & $11.32 \mathrm{~b}$ \\
$\mathrm{~T} 2$ & $8.33 \mathrm{~b}$ & $3.91 \mathrm{a}$ & $25.84 \mathrm{a}$ & $10.87 \mathrm{~b}$ & $15.45 \mathrm{a}$ \\
$\mathrm{T} 3$ & $6,10 \mathrm{c}$ & $4.44 \mathrm{a}$ & $22.65 \mathrm{~b}$ & $7.90 \mathrm{c}$ & $11.25 \mathrm{~b}$ \\
T4 & $3.77 \mathrm{~d}$ & $1.97 \mathrm{~b}$ & $18.96 \mathrm{dc}$ & $5.32 \mathrm{~d}$ & $4.97 \mathrm{c}$ \\
T5 & $8.33 \mathrm{~b}$ & $3.37 \mathrm{a}$ & $17.95 \mathrm{ed}$ & $5.42 \mathrm{~d}$ & $4.57 \mathrm{c}$ \\
T6 & $12.94 \mathrm{a}$ & $4.07 \mathrm{a}$ & $20.64 \mathrm{cb}$ & $12.45 \mathrm{a}$ & $15.42 \mathrm{a}$ \\
\hline CV\% & 6.05 & 12.98 & 3.78 & 6.74 & 6.24 \\
\hline
\end{tabular}

The positive effect of the substrate enriched with organic compounds may be related to the higher availability of $\mathrm{P}, \mathrm{Ca}, \mathrm{Mg}$, and $\mathrm{K}$, besides the $\mathrm{pH}$ at favorable levels to plant development. In addition, substrates containing organic compounds have adequate cation exchange capacity (CEC), influencing the nutritional status (Cunha et al., 2006).

The lowest values observed in T4 (sand + coconut fiber) (Table 3) may be due to the reduction of nutrients in this composition. Despite presenting good physical characteristics and being an option to improve the substrates quality, coconut fiber must undergo the composting process. Otherwise, this material needs to be enriched with pre-planting or fertigation nutrients when used as a substrate (Carrijó et al., 2002).

Morphological parameters are the most used to determine seedling quality standard due to their ease evaluation. Seedling height and stem diameter are directly related to survival, establishment, and initial growth. Despite being efficient, when it comes to native or non-domesticated species, these patterns have not been defined yet (Oliveira et al., 2014). Vieria and Weber (2015) verified that jenipapo seedlings grown in substrates containing different soil proportions + Basaplant ${ }^{\circledR}$ presented stem diameter between 2.75 and $2.92 \mathrm{~mm}$. In mangaba seedlings (Hancornia speciosa Gomes), the substrate constituted by $14 \%$ bovine manure, $56 \%$ vegetal soil, $15 \%$ coconut fiber, $15 \%$ sand, and $4 \mathrm{~g} \mathrm{dm}^{-3}$ of triple superphosphate provided greater growth and nutritional balance (Dias et al., 2009). Moringa (Moringa oleifera Lam.) seedlings height presented higher values at a shorter cultivation time with the use of $50.75 \%$ and $100 \%$ of organic matter (Rodrigues et al., 2016). Studies on guapuruvú seedlings (Schizolobium parahyba Vell. Blake) indicated that substrates containing organic nutrient source (earthworm humus) favored seedlings growth (Castro et al., 2014). In candeia seedlings (Eremanthus erythropappus), the lowest growth rate was observed when bovine manure was used in the substrate composition (Melo et al., 2014).

T2 (Table 3) stood out for root length, with $25.84 \mathrm{~cm}$. This result might be related to the fact that the substrate composition (fertilized soil + coconut fiber) contains a high organic matter content, and thus meets the requirements of the plant, allowing good root development. The use of organic residues in substrates composition can contribute to an adequate water retention capacity, good aeration, and a physical structure that allows appropriate root growth (Silva et al., 2008). Mesquita et al. (2011) suggest that using coconut powder with sand and/or manure does not minimize the actions of tannins and phenols. This fact was verified in T4 and T5, which registered the lowest means, 18.96 and $17.96 \mathrm{~cm}$, respectively. The use of coconut fiber + vegetal soil (1: 3) in cassia-grande (Cassia grandis L.) seedlings provided the best results for this trait.

Shoot dry matter was high (12.45 g) in the T6 (bovine manure + sand); (Table 3). For root dry matter, T2 (fertilized soil + coconut fiber) and T6 (bovine manure + sand) did not differ between each other, resulting in higher values, $15.42 \mathrm{~g}$ and $15.45 \mathrm{~g}$, respectively (Table 3 ). T4 (sand + coconut fiber) and T5 (bovine manure + coconut fiber) presented the lowest values for both shoot (5.32 and 5.42, respectively) and root dry matter (4.97 and 4.57, respectively). These values indicate the influence of the substrate on the plant development since the increase of dry matter production is possibly related to the best physical and biological conditions of the substrate. For the plant to have optimum growth and dry matter, the substrate must present ideal characteristics, such as aeration, structure, and water retention capacity (Guedes et al., 2011).

For the species Parkia platycephala Benth, the substrate coconut powder did not favor root and shoot dry matter (Silva et al., 2017). In jenipapo seedlings, Primo et al. (2013) verified higher root and shoot dry matter when using the substrate tobacco stem + bovine manure.

Different substrates influenced the number of leaves, leaf area (LA), leaf area ratio, and relative chlorophyll content (SPAD), highlighting the treatments T1 (fertilized soil), T2 (fertilized soil + coconut fiber), T3 (fertilized 
soil + sand), and T6 (bovine manure + sand) (Figure 1A, 1B, 1C, and 1D, respectively). Costa et al. (2005) stated that bovine manure favored the greatest number of leaves in jenipapo seedlings.
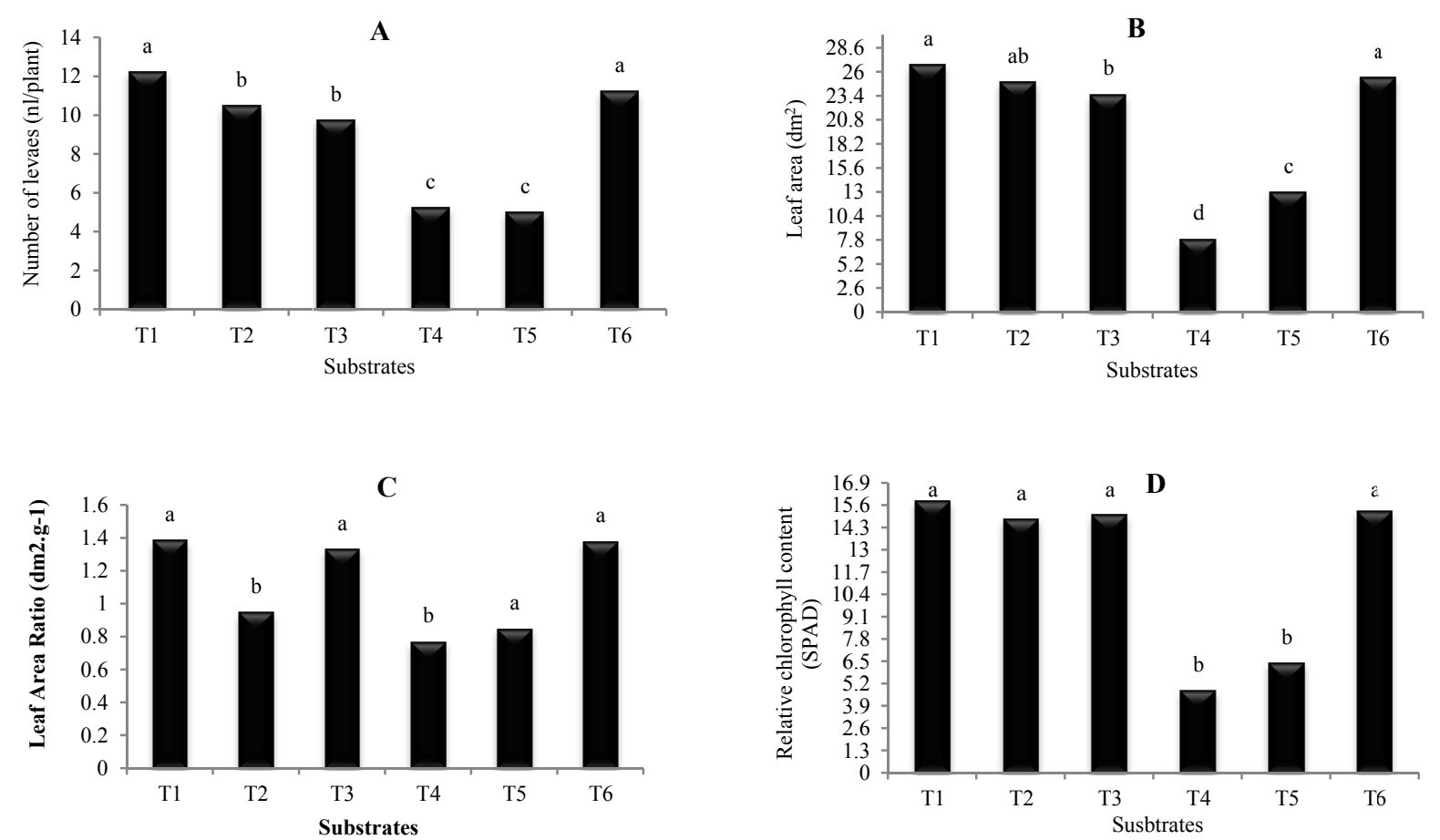

Figure 1. (A) Number of leaves; (B) Leaf area; (C) Leaf area ratio and (D) Relative chlorophyll content in jenipapo seedlings subjected to different substrate compositions

Treatments with higher chlorophyll content might have provided satisfactory nitrogen amounts to jenipapo seedlings. Hardin et al. (2012) found a positive correlation between SPAD index and total chlorophyll content in pecan (Carya illinoinensis (Wang.) K. Koch]). In jenipapo-bravo (Tocoyena formosa (Cham. \& Schltdl.), the highest chlorophyll index was observed in plants grown in substrate containing poultry litter (Bonamigo et al., 2016).

Studies on seedlings and plants management in the field are required to improve the jenipapo production system. One way to facilitate the production and nursery establishment without the need for a complex infrastructure is using alternative substrates available in the region, either in their pure form or in admixture with other materials. Substrates such as pure fertilized soil, coconut fiber, bovine manure, and the mixture of these materials can be used for jenipapo cultivation, reducing production costs.

\section{Conclusion}

The substrate fertilized soil (T1); fertilized soil + coconut fiber (T2); fertilized soil + sand (T3), and bovine manure + sand (T6) can be used for jenipapo seedlings production without impairing seedlings growth.

\section{References}

Abud, H. F., Reis, R. G. E., \& Teófilo, E. M. (2009). Morphological characterization of fruits, seeds, seedlings and germination of Mucuna aterrima Piper \& Tracy. Revista Ciência Agronômica, 40, 563-569.

Almeida, C. S., Silva, A. V. C., Araújo, M. A. G., \& Lédo, A. S. (2015). Morphogenetic responses of jenipapo in different in vitro culture conditions. Revista Caatinga, 28, 58-64.

Alves, E. U., Andrade, L. A., Bruno, R. L. A., Vieira, R. M., \& Cardoso, E. A. (2011). Emergence and early growth of Peltophorum dubium (Spreng.) Taubert seedlings under different substrata. Revista Ciência Agronômica, 42, 439-447. https://doi.org/10.1590/S1806-66902011000200025 
Araújo, A. P., \& Paiva Sobrinho, S. (2011). Germination and production of seedlings of tamboril (Enterolobium Contortisiliquum (Vell.) Morong) on different substrates. Revista Árvore, 35, 581-588. https://doi.org/ 10.1590/S0100-67622011000400001

Bonamigo, T., Scalon, S. P. Q., \& Pereira, Z. V. (2016). Substrates and levels of light intensity on initial growth of seedlings of Tocoyena formosa (Cham. \& Schltdl.) K. Schum. (Rubiaceae). Ciência Florestal, 26, 501-511. https://doi.org/10.5902/1980509822750

Brasil, Ministério da Agricultura, Pecuária e Abastecimento. (2009). Regras para análise de sementes (p. 399). Brasília: Secretaria de Defesa Agropecuária/MAPA/ACS. Retrieved from http://www.agricultura.gov.br/ assuntos/insumos-agropecuarios/arquivos-publicacoes-insumos/2946_regras_analise_sementes.pdf

Carrijo, O. A., Liz, R. S., \& Makishima, N. (2002). Fiber of green coconut shell as an agricultural substrate. Horticultura Brasileira, 20, 533-535. https://doi.org/10.1590/S0102-05362002000400003

Castro, L. H. S., Freitas, C. H., Santos, D. R., \& Silva, J. F. (2014). Substrate composition and physiological parameters of growth of seedlings guapuruvu (Schizolobium parahyba vell. blake). Revista Brasileira de Agropecuária Sustentável, 4, 70-75. https://doi.org/10.21206/rbas.v4i1.238

Coelho, M. F. B., Souza Filho, J. C., Azevedo, R. A. B., Dombroski, J. L. D., \& Maia, S. S. S.(2010). Substrata effect on Magonia pubescens St.Hil. seed emergence. Revista Brasileira de Ciencias Agrárias, 5(1), 80-84. https://doi.org/10.5039/agraria.v5i1a572

Costa, M. C., Albuquerque, M. C. F., Albrecht, J. M. F., \& Coelho, M. F. B. (2005). Substrates for production of jenipapo (Genipa americana L.). Pesquisa Agropecuária Tropical., 35(1), 19-24.

Cunha, A. M., Cunha, G. M., Sarmento, R. A., Cunha, G. M., \& Amaral, J. F. T. (2006). Effect of different substrates on the development of Acacia sp. seedlings. Revista Árvore, 30, 207-214. https://doi.org/10.1590/ S0100-67622006000200007

Dias, T. J., Pereira, W. E., Cavalcante, L. F., Raposo, R. W. C., \& Freire, J. L. O. (2009). Development and nutritional quality of Hancornia speciosa seedlings cultivated in mixture containing coconut fiber and fertilized with phosphorus. Revista Brasileira de Fruticultura, 31, 512-523. https://doi.org/10.1590/ S0100-29452009000200028

Freitas, A. F., Souza, L. A. G., Cardoso, I. M., \& Paiva, H. N. (2014). Fine coal in substrate for Dipteryx odorata seedlings. Revista Brasileira de Agroecologia, 9, 31-40.

Gondin, J. C., Silva, J. B., Alves, C. Z., Dutra, A. S., \& Elias Junior, L. (2015). Seedling emergence in Schizolobium amazonicum Huber ex Ducke (Caesalpinaceae) in different substrates and shading. Revista Ciência Agronômica, 46, 329-338. https://doi.org/10.5935/1806-6690.20150012

Guedes, R. S., Alves, E. U., Gonçalves, E. P., França, P. R. C., Moura, M. F., \& Santos, S. da S. (2011). Germination of Dalbergia nigra (Vell.) Fr. All. seeds. Acta Scientiarum - Biological Sciences, 33, 445-450. https://doi.org/10.4025/actascibiolsci.v33i4.5834

Hardin, J. A., Smith, M. W., Weckler, P. R., \& Cheary, B. S. (2012). In Situ Measurement of Pecan Leaf Nitrogen Concentration using a Chlorophyll Meter and Vis-near Infrared Multispectral Camera. Hortscience, 47, 955-960.

Leal, C. C. P., Torres, S. B., Brito, A. A. F., Freitas, R. M. O., \& Nogueira, N. W. (2016). Emergency and initial development of Cassia grandis L. f. plants according to different substrates. Ciência Florestal, 26, 727-734. https://doi.org/10.5902/1980509824196

Magistrali, P. R., José, A. C., Faria, J. M. R., \& Gasparin, E. (2013). Physiological behavior of Genipa americana L. seeds regarding the capacity for desiccation and storage tolerance. Journal of Seed Science, 35, 495-500. https://doi.org/10.1590/S2317-15372013000400011

Maguire, J. D. (1962). Speed of germination-aid in selection and evaluation for seedlings emergence and vigor. Crop Science, 2, 176-177. https://doi.org/10.2135/cropsci1962.0011183X000200020033x

Melo, L. A., Pereira, G. A., Moreira, E. J. C., Davide, C. A., Silva, E. V., \& Teixeira, L. A. F. (2014). Growth of Eucalyptus grandis and Eremanthus erythropappus Seedlings under Different Substrate Formulas. Floresta e Ambiente, 21, 234-242. https://doi.org/10.4322/floram.2014.028

Mesquita, J. B., Santos, M. J. C., Ribeiro, G. T., \& Moura, A. O. (2011). The composition avaliation of substrata and containers in the production of jenipapo seedlings (Genipa americana L.). Natural Resources, 1, 37-45. https://doi.org/10.6008/ESS2237-9290.2011.001.0004 
Moraes, L. A. C., Garcia, T.B., Sousa, N.R., \& Moreira, A. (2007). Induction of apical bud sprouting in seedlings and rooting of cuttings of mangosteen. Acta Scientiarum Agronomy, 29, 665-669, https://oi.org/10.1590/ S1807-86212007000500011

Nakagawa, J. (1999). Testes de vigor baseados no desempenho das plântulas. In F. C. Krzyzanowski, R. D. Vieira, J. B. França Neto (Eds.), Vigor de sementes: conceitos e testes (Vol. 2, pp. 1-21). Londrina: ABRATES.

Oliveira, L. R., Lima, S. F., \& Lima, A. P. L. (2014). Growth of cedar seedlings at diferente substrates. Brazilian Journal of Forestry Research, 34, 187-195. https://doi.org/10.4336/2014.pfb.34.79.605

Osipi, E. A. F., Lima, C. B., \& Cossa, C. A. (2011). Influence of methods of aryl remotion on physiology and quality of Passiflora alata. Revista Brasileira de Fruticultura, 33, 680-685. https://doi.org/10.1590/ S0100-29452011000500095

Primo, D. C., Fadigas, F. S., Pereira, R. C., \& Santos, L.G. (2013). Use of organic compost from the tobacco (Nicotiana tabacum L.) Cultivation in the composition of background to the production of tree seedlings. Scientia Plena, 9, 1-9.

Queiroz, S. E. E., Silva, E. A. A., Davide, A. C., José, A. C., Silva, A. T., Fraiz, A. C. R., ... Hilhorst, H. W. M. (2012). Mechanism and control of Genipa Americana seed germination. Physiologia Plantarum, 144, 263-276. https://doi.org/j.1399-3054.2011.01554.x

Rodrigues, L. A., Muniz, T. A., Samarão, S. S., \& Cyrino, A. E. (2016). Quality of Moringa oleifera Lam. seedlings cultivated in substrates with green coconut fiber and organic compounds Revista Ceres., 63, 545-552. https://doi.org/10.1590/0034-737X201663040016

Santana, D. G., Wielewicki, A. P., \& Salomão, N. A. (2012). Validation of quality tests for forest seed species. Seed Science Research, 22, 74-79. https://doi.org/10.1017/S096025851100033X

Scalon, S. P. Q., \& Jeromine, T. S. (2013). Substrate and water levels on the germinative potential of seeds of uvaia. Revista Árvore, 37, 49-58. https://doi.org/10.1590/S0100-67622013000100006

Silva, E. A., Maruyama, W. I., Oliveira, A. C., \& Bardivi, D. M. (2009). Effect of different substrates on the production of mangabeira seedlings (Hancornia speciosa). Revista Brasileira de Fruticultura, 31, 925-929. https://doi.org/10.1590/S0100-29452009000300043

Silva, E. A., Mendonça, V., Tosta, M. S., Oliveira, A. C., Reis, L. L., \& Bardiviesso, D. M. (2008). Germination of seeds and production of seedlings of lettuce cultivars at different substrates. Semina, 29, $245-254$. https://doi.org/10.5433/1679-0359.2008v29n2p245

Silva, R. B., Matos, V. P., Farias, S. G., Sena, L. H. M., \& Silva, D. Y. B. O. (2017). Germination and seedling vigour in Parkia platycephala Benth. in different substrates and temperatures. Revista Ciência Agronômica, 48, 142-150. https://doi.org/10.5935/1806-6690.20170016

Vieira, C. R., \& Weber, O. L. S. (2015). Substrate influence on seedlings productions of medical species. Nativa, 3, 135-142. https://doi.org/10.14583/2318-7670.v03n02a11

\section{Copyrights}

Copyright for this article is retained by the author(s), with first publication rights granted to the journal.

This is an open-access article distributed under the terms and conditions of the Creative Commons Attribution license (http://creativecommons.org/licenses/by/4.0/). 